ROCZNIKI HISTORYCZNE

Rocznik LXXXI - 2015

ANDRZEJ RADZIMIŃSKI (Toruń)

\title{
Dyspensy de diversis formis dla polskiego duchowieństwa Z dziejów stosowania prawa kanonicznego i obyczajowości w późniejszym średniowieczu
}

Prowadząc badania nad duchowieństwem w Polsce średniowiecznej, zwróciłem uwagę na dyspensy papieskie pochodzące najczęściej z ksiąg Penitencjarii Apostolskiej $^{1}$. Dokumenty te do $1471 \mathrm{r}$. zostały wydane - choć z wieloma błędami - w Bullarium Poloniae. Co ważne i raczej wyjątkowe w tej edycji, były one publikowane zwykle niemal w całości ${ }^{2}$. Akta Penitencjarii Apostolskiej zostały ponadto dla lat 1431-1513 opublikowane w postaci regestów w ramach serii Repertorium Poenitentiariae Germanicum przygotowywanego przez Niemiecki Instytut Historyczny w Rzymie ${ }^{3}$. W niemieckiej historiografii pojawiły się również pierwsze oparte na tych aktach monografie poświęcone życiu i obyczajowości średniowiecznego społeczeństwa ${ }^{4}$. Szwedzcy historycy wydali in extenso tego typu dokumenty z lat 1410-1526, kierowane w tym czasie do Penitencjarii przez duchownych czynnych w granicach szwedzkiej metropolii ze stolicą w Uppsali ${ }^{5}$. Tego typu dokumenty stały

${ }^{1}$ Klasyczne już opracowanie na temat Penitencjarii Apostolskiej dał E. Gö 11 e r, Die päpstliche Poenitentiarie von ihrem Ursprung bis zu ihrer Umgestaltung unter Pius V., t. I-II, Rom 1907-1911, a także np. F. Ta mburin i, Santi e peccatori. Confessioni e suppliche dai Registri della Penitenzieria dell'Archivio Segreto Vaticano (1451-1586), Milano 1995; K. S a lon e n, L. S chmugge, A Sip from the „Well of Grace”. Medieval texts from the Apostolic Penitentiary, Washington 2010; w literaturze polskiej: ks. P. S te c z k ow ski, Penitencjaria Apostolska (XIII-XVI w.). Powstanie, ewolucja, odnowienie, Rzeszów 2013.

${ }^{2}$ Bullarium Poloniae, wyd. I. Sułkowska-Kuraś, S. Kuraś, t. I-VII, Romae-Lublini 19822006 (dalej cyt.: BP). Według informacji wydawców akta Penitencjarii zostały uwzględnione w t. III, V-VII, obejmujących lata 1378-1417, 1431-1449, 1447-1464 oraz 1464-1471. Niemniej dodajmy, że dyspensy super defectu perfectae lenitatis, pochodzące jednak z Regestów Suplik i Regestów Laterańskich, zostały opublikowane także w t. IV dla lat 1417-1431 (zob. tam np. nr 193, 618, 711, 838, 1175, 1877, 2273, 2311, 2394, 2470). O edycji tej zob. M. D. K o w a 1 s k i, Krytyczne uwagi o najnowszym, siódmym tomie „Bullarium Poloniae”, Roczniki Historyczne 73, 2007, s. 214-230.

${ }^{3}$ Repertorium Poenitentiariae Germanicum. Verzeichnis der in den Suplikenregistern der Pönitentiariae vorkommenden Personen, Kirchen und Orte des Deutschen Reiches, wyd. L. Schmugge i inni, t. I-IX, Tübingen-Berlin-Boston 1998-2014.

${ }^{4}$ Zob. np. A. E s c h, Wahre Geschichten aus dem Mittelalter. Kleine Schicksale selbst erzählt in Schreiben an den Papst, München 2010.

${ }_{5}$ Auctoritate papae. The Church Province of Uppsala and the Apostolic Penitentiary 14101526, wyd. S. Risberg, wstęp K. Salonen, Stockholm 2008. Zob. także prace K. S a l o n e n zebrane w przyp. 7, poświęcone relacjom duchowieństwa metropolii w Uppsali z Penitencjarią. 
się również podstawą kilku moich artykułów ${ }^{6}$, ukazujących przede wszystkim różne obszary obyczajowości średniowiecznego społeczeństwa, w tym przede wszystkim życie codzienne kleru i kobiet, ale także pozwalających zorientować się, w jaki sposób duchowni rozumieli przepisy prawa kanonicznego i starali się ich przestrzegać. W prezentowanym obecnie artykule zamierzam przedstawić analizę tego typu dokumentów, pochodzących z okresu od końca XIV w. do lat siedemdziesiątych $\mathrm{XV}$ w., przede wszystkim pod względem ich interpretacji prawnych. Pozwoli to również na sformułowanie oceny na temat podejścia duchownych do obowiązującego prawa kanonicznego. Rozważaniom prawnym będą oczywiście towarzyszyły barwne opisy średniowiecznej codzienności. Chociaż omawiane dokumenty należą do źródeł, które dopiero od niedawna stały są dostępne dla badaczy (księgi Penitencjarii Apostolskiej udostępniono historykom dopiero w 1983 r. w wyniku decyzji papieża Jana Pawła II), to jednak coraz częściej są wykorzystywane w europejskich badaniach mediewistycznych, także do badań na średniowieczną obyczajowością7. Biorąc zatem pod uwagę stosunkowo nieliczne kategorie źródeł, jakimi w zakresie omawianej problematyki dysponują polscy historycy, dyspensy papieskie mają szansę wnieść nową jakość do dotychczasowych badań nad duchowieństwem ${ }^{8}$.

${ }^{6}$ A. R a d zi m iń s ki, ,...super irregularitate, si quam propterea incurrit”. Dyspensy ex defectu perfectae lenitatis duchowieństwa w okresie pontyfikatu Marcina V, w: Venerabiles, nobiles et honesti. Studia z dziejów społeczeństwa Polski średniowiecznej. Prace ofiarowane Profesorowi Januszowi Bieniakowi w siedemdziesiątą rocznicę urodzin i czterdziestopięciolecie pracy naukowej, Toruń 1997, s. 115-124; t e n ż e, Kobieta w dokumentach papieskich z okresu pontyfikatu Marcina V (1417-1431), w: Kobieta i rodzina w średniowieczu i na progu czasów nowożytnych, Toruń 1998, s. 45-56; t e n ż e, Dispensen super defectu perfectae lenitatis. Die Konflikte des spätmittelalerlichen Klerus und die Methoden ihrer Bewältigung, w: Konfliktbewältigung und Friedensstiftung im Mittelalter, Toruń 2012, s. 277-288; t e n ż e, The women in papal documents of the Late Middle Ages, Quaestiones Medii Aevi Novae 19, 2014, s. 33-53; t e n ż e, Z życia codziennego polskiego duchowieństwa średniowiecznego. Pobicia, zranienia i bójki (w druku).

7 Jedynie tytułem przykładu podam kilka najnowszych, ważniejszych opracowań z tego zakresu: P. Clarke, Central authority and local powers. The Apostolic Penitentiary and the English Church in the fifteenth century, Historical Research 84 (225), 2011, s. 416-442; K. S a 1 on e n, The Penitentiary as a Well of Grace in the Late Middle Ages. The Example of the Province of Uppsala 1148-1527, Annales Academiae Scientiarum Fennicae 313, Saarijärvi 2001; t a ż, Kommunikation zwischen der Pönitentiarie und der partes im Spätmittelalter. Die Provinz von Uppsala als Beispiel, w: The Roman Curia, the Apostolic Penitenciary and the Partes in the Later Middle Ages, Acta Instituti Romani Finlandiae 28, 2003, s. 23-32; K. S a lon en, L. S chmugge, A Sip; w literaturze polskiej zob. np. M. S a c z y ń ska, Supliki polskich duchownych w archiwum Penitencjarii Apostolskiej (1471-1492), w: Fundamenty średniowiecznej Europy, Pelplin 2013, s. 187-202 (tam dalsza literatura); t a ż, Supliki polskie w najstarszej księdze Penitencjarii Apostolskiej (Registra matrimonialium et diversorum, t. 1), w: Ecclesia, regnum, fontes. Studia z dziejów średniowiecza ofiarowane Profesor Marii Koczerskiej, Warszawa 2014, s. 110-118.

${ }^{8}$ Dotychczas w takich badaniach były wykorzystywane np. akta synodalne polskich biskupów (na podstawie których Jan Fijał e k napisał książkę pt. Życie i obyczaje kleru w Polsce średniowiecznej, wyd. 2, Kraków 1997), akta konsystorskie, akta i statuty kapituł katedralnych i kolegiackich, różnego typu rachunki duchownych i instytucji kościelnych. Zob. np. A. K o w a l s k a - P i e tr z a k, W kręgu średniowiecznego duchowieństwa łęczyckiego, Łódź-Łęczyca 2012, w której znajdujemy (s. 53-105) podrozdział „Łęczycka codzienność. 
Są to bowiem źródła, które pokazują - poza aspektami prawnymi - wiele ciekawych i różnorodnych sytuacji z życia średniowiecznego społeczeństwa, niekiedy wzbogacając swoją narrację niezwykle interesującymi dialogami. Dialogi te sprawiają wrażenie, jakby miały podkreślać opisywaną przez duchownych sytuację, nadać jej dodatkowej ekspresji, bardziej przekonać do ich wersji różnych sytuacji przedstawionych w dokumentach. Są zapisywane w języku łacińskim, chociaż bez wątpienia musiały być wypowiadane $w$ języku ludowym.

Zagadnienia związane z uzyskiwaniem przez duchownych dyspens w Penitencjarii Apostolskiej pokażę przez pryzmat jej działalności, posiadanego zakresu kompetencji oraz obowiązujących przepisów prawa kanonicznego. Przy okazji przedstawię także bardzo ciekawą warstwę obyczajową związaną z życiem codziennym duchowieństwa. Zasadnicza teza, którą stawiam w tym kontekście, dotyczy znajomości, rozumienia oraz przestrzegania przez duchowieństwo obowiązujących przepisów prawa kanonicznego. Powstanie Penitencjarii Apostolskiej poprzedziła już na przełomie X i XI w. działalność w kurii papieskiej prezbiterów, którzy byli wyznaczani przez papieża do spowiadania wiernych przybywających w tym celu do Rzymu. Początkowo wierni ci udawali się do Wiecznego Miasta jedynie z nakazu biskupów diecezjalnych, którzy dostrzegali potrzebę zaostrzenia różnych form pokuty za szczególnie ciężkie przewinienia. Spowiedź przed wspomnianym prezbiterem była potwierdzana specjalnym dokumentem. W XII w. - w wyniku rozwoju prawa kanonicznego, a także dookreślenia zasady papieskiej plenitudo potestatis również w zakresie odbywania pokuty - stopniowo zaczęły pojawiać się papieskie rezerwaty. Jednakże jeszcze przed ich wprowadzeniem do przepisów prawa kanonicznego ukształtowała się praktyka, iż w przypadku poważnych wykroczeń przeciwko prawu kościelnemu, ale także zasadom moralności, ich sprawcy byli odsyłani do Rzymu po uzyskanie dyspensy. Do takich występków można zaliczyć np. morderstwo, gwałt, zabójstwo rodziców, zabójstwo duchownego, kazirodztwo, sodomię, świętokradztwo, symonię. Katalogi takich występków były formułowane przez synody diecezjalne. Omawiane rezerwaty dawały papieżowi prawo do rozgrzeszania penitentów ze szczególnie ciężkich grzechów, a także uwalniania z nałożonych na nich kar kościelnych ${ }^{9}$. Pierwszy rezerwat papieski został ustanowiony na II Soborze Laterańskim w 1139 r. Dotyczył on prawa do udzielania dyspensy tym, którzy dopuścili się przemocy wobec duchownych świeckich lub zakonników i w konsekwencji zostali obłożeni ekskomuniką ${ }^{10}$. Rezerwat ten został włączony do pierwszej kodyfikacji prawa kanonicznego, czyli Dekretu

Obrazki z życia kleru", w znacznej części opracowany na podstawie rachunków kapituły kolegiackiej w Łęczycy z pierwszej połowy XV w., przy czym autorka wykorzystała również bogate akta konsystorskie. Wspomniane powyżej typy źródeł wykorzystałem także w pracy: Życie i obyczajowość średniowiecznego duchowieństwa, Warszawa 2002. Dodajmy przy okazji, że niczego właściwie na temat obyczajowości średniowiecznego duchowieństwa nie dowiadujemy się z krakowskiej syntezy: Obyczaje w Polsce. Od średniowiecza do czasów współczesnych, red. A. Chwalba, Warszawa 2004 (rozdział poświęcony wiekom średnim napisała L. K o r c z a k).

9 P. S te c zk ow ski, Penitencjaria, s. 47-51.

${ }_{10}$ Dokumenty soborów powszechnych, t. II, opr. A. Baron, H. Pietras, Kraków 2002, s. 152, kanon 15 (Ut excommunicetur clerici percussor et qui manus iniecerit in eum qui ad ecclesiam vel coemeterium confugit). 
Gracjana, pod nazwą Si quis suadente diabolo ${ }^{11}$. Supliki w takich sprawach składały także osoby z Polski, na co wskazują m.in. dwie przykładowe dyspensy udzielone w okresie pontyfikatu papieża Pawła II, z których pierwsza odnosiła się do osoby świeckiej, druga zaś - do duchownego. W dokumencie datowanym 1 IX $1466 \mathrm{r}$. czytamy, że Piotr z Łomży, świecki diecezji płockiej, zabił kiedyś w obronie własnej, ale za namową diabła, pewnego kapłana, za co został ekskomunikowany. W wyniku supliki skierowanej do Penitencjarii otrzymał stosowną dyspensę. Decyzja w sprawie Piotra została opatrzona formułą Fiat in forma, co oznaczało, że podjęto ją zgodnie z procedurami obowiązującymi w Penitencjarii ${ }^{12}$. Druga tego typu dyspensa dotyczyła Stanisława de Scarmina, kapłana diecezji krakowskiej, który diabolo instigante, spalił pewnemu plebanowi stodołę i dwie stajnie ze zbożem i innymi rzeczami, a także nie zwracając uwagi na konsekwencje ekskomuniki, nadal wykonywał funkcje kapłańskie i tym samym popadł pod dodatkową karę kanoniczną zwaną irregularitas. Również i on uzyskał stosowną dyspensę, tym razem jednak opatrzoną inną formułą: Fiat de speciali, co oznaczało, że decyzję podjęto na podstawie upoważnienia lub przywileju papieskiego. Dyspensa ta miała charakter komisaryczny. Taka komisaryczna forma udzielania łaski polegała na tym, że najczęściej biskup diecezjalny w miejscu działalności petenta miał potwierdzić, czy sprawa przedstawiona w suplice odpowiadała rzeczywistości ${ }^{13}$. Do tego typu dyspens powrócę w dalszej części tekstu.

Dalsze rezerwaty papieskie w konkretnych sprawach były ogłaszane w bullach kolejnych papieży. Do słuchania spowiedzi i udzielania pokuty w sprawach objętych takimi rezerwatami już w XII w. został utworzony urząd penitencjarza papieskiego, który po pewnym czasie otrzymał nazwę penitencjarza większego. Ponieważ wiek XIII przyniósł znaczący wzrost spraw do niego kierowanych, spowodowało to konieczność stworzenia w kurii papieskiej instytucji biurokratycznej, która została nazwana Penitencjarią Apostolską ${ }^{14}$. Warto jednak podkreślić, że jeszcze w XII i XIII w. papieże udzielali niekiedy biskupom prawa do udzielania dyspensy w sprawach zarezerwowanych do kompetencji papieskiej. Dla Polski pierwszy znany mi przykład pochodzi z kwietnia 1193 r., kiedy to Celestyn III odpowiedział pozytywnie na pytanie ówczesnego biskupa krakowskiego, czy może on dyspendować Alaryka, kapłana diecezji krakowskiej. Duchowny ten, nie mogąc odzyskać długu od pewnego świeckiego, spotkał się z nim, jednakże w trakcie tego spotkania nie tylko nie odzyskał pożyczki, lecz otrzymał cios pięścią. Zrewanżował się zranieniem dłużnika mieczem, w wyniku czego tamten zmarł. W konsekwencji papież udzielił biskupowi krakowskiemu prawa do udzielenia dyspensy wspomnianemu

${ }_{11}$ Zob. R. H. Hel mholz, „Si quis suadente” (C. 17 q. 4 c. 29). Theory and practice, w: Proceedings of the Seventh International Congress of Medieval Canon Law, Cambridge, 23-27 July 1984, Città del Vaticano 1988, s. 425-438; t e n ż e, The Oxford History of the Laws of England, t. I: The Canon Law and Ecclesiastical Jurisdiction from 597 to the 1640, Oxford 2004, s. 505-510.

${ }^{12}$ BP VII, nr 333 (quod ipse olim se deffendendo dyabolo suadente quendam presb. interfecit, propter quod excomunicacionis sentenciam et presbitericidii reatum incurrit sentenciam in tales generaliter promulgatam); zob. też $\mathrm{nr}$ 182, 183, 189.

${ }_{13}$ BP VII, nr 645; zob. K. S a 1 o n e n, L. S c h mu g g e, A Sip, s. 74-76.

14 Tamże, s. 13-68. Zagadnienia związane z tworzeniem się Penitencjarii omawia w polskiej historiografii ks. P. S t e c z k ow s ki, Penitencjaria, s. 67-97. 
duchownemu ${ }^{15}$. Inny przykład pokazuje bulla papieża Bonifacego VIII z 12 VI 1296 r., w której udzielił biskupowi kamieńskiemu Piotrowi prawo do dyspendowania 100 duchownych i świeckich w jego diecezji, którzy w sposób gwałtowny podnieśli rękę na duchownych i ściągnęli tym samym na siebie ekskomunikę ${ }^{16}$.

Penitencjaria Apostolska otrzymała od papieży prawo do udzielania czterech typów łask: 1) absolucji z grzechów naruszających normy prawa Bożego i kanonicznego; 2) dyspendowania od łamania przepisów obowiązującego prawa kanonicznego; 3) wydawania różnego rodzaju licencji na podejmowanie działań niezgodnych z obowiązującą praktyką; 4) składania deklaracji w różnych sprawach. Sprawy znajdujące się w suplikach kierowanych do Penitencjarii można zasadniczo podzielić na siedem kategorii, wyróżnianych przez pracowników kancelaryjnych: 1) de matrimonialibus - prośby odnoszące się do sakramentu małżeństwa; 2) de diversis formis - prośby w różnych sprawach; 3) de declaratoribus - prośby o wydanie wspomnianych deklaracji; 4) de defectu natalium - prośby związane z pochodzeniem z nieprawego łoża; 5) de uberiori - prośby w kwestiach beneficjalnych; 6) de promotis et promovendis - prośby związane z wejściem do stanu duchownego i uzyskanymi święceniami; 7) de confessionalibus - prośby związane z sakramentem pokuty ${ }^{17}$.

Omawiając kompetencje Penitencjarii oraz kwestie prawne występujące w poszczególnych dyspensach, skupię się przede wszystkim na takich sprawach, które były katalogowane pod wspólnym tytułem de diversis formis, i jedynie wskażę przykładowo na inne kategorie. Dyspensy de diversis formis były udzielane przede wszystkim W związku z popełnieniem występków dotyczących poważnego naruszenia prawa kościelnego, czego konsekwencją było nałożenie na obwinione osoby odpowiednich kar kościelnych. Poza bójkami, udziałem w wojnach oraz użyciem broni możemy do nich zaliczyć np. złamanie zobowiązań do zachowania czystości, do podjęcia życia zakonnego i złożenia ślubów (a nawet samego przyrzeczenia prowadzenia takiego życia), do odbycia pielgrzymki do Rzymu, Jerozolimy lub Santiago de Compostela. Ponadto Penitencjaria udzielała dyspens, znów należących do kategorii de diversis formis, w różnych innych sprawach, np. w przypadku symonii, świętokradztwa, wspomnianej już przemocy wobec duchownych, znieważenia kościoła lub innego miejsca świętego, nadużyć w sprawowaniu sakramentów, wykonywania czynności liturgicznych bez uprawnień, krzywoprzysięstwa, handlu z muzułmanami, fałszowania dokumentów, przyjmowania święceń od włoskich biskupów wbrew zakazowi papieża, popadnięcia w herezję. Innym rodzajem dokumentów wydawanych przez Penitencjarię Apostolską, które również rejestrowano pod nazwą de diversis formis, były licencje, czyli różnego rodzaju zezwolenia, o które starali się wierni, a niekiedy nawet całe parafie i regiony. Dotyczyły one różnych kwestii, jak np. zwolnienia z przestrzegania zasad Wielkiego Postu lub nabycia prawa do używania ołtarza przenośnego. Osoby chore, ubogie czy też wykonujące ciężką pracę starały się o prawo do spożywania w okresie postnym jaj, mleka, sera i masła. Dokumenty takie określano jako „listy maślane”, a supliki o nie kierowano najczęściej z krajów

15 BP I, nr 36.

16 BP I, nr 931.

${ }^{17}$ K. Salon e n, L. S c h mugge, A Sip, s. 17-68; P. S te c z k ow ski, Penitencjaria, s. $99-117$. 
położonych w północnych regionach kontynentu, a także w górskich regionach Europy Środkowej ${ }^{18}$. Istniały również „listy mięsne”, pozwalające na spożywanie mięsa w czasie postu. Do Penitencjarii składane były ponadto supliki o dyspensy w związku z zamiarem działania w ważnych sprawach wbrew prawu ${ }^{19}$. Przeważająca jednak liczba suplik kierowanych do Penitencjarii z diecezji metropolii gnieźnieńskiej oraz diecezji przyległych dotyczyła uzyskania dyspensy od ekskomuniki oraz zaciągnięcia wadliwości (irregularitas) przy przyjmowaniu święceń lub też dodatkowo od dalszego wykonywania funkcji wynikających z tak uzyskanych święceń. Powodem nakładanych na duchownych ekskomunik, a także zaciągania wadliwości, było przede wszystkim zabójstwo lub stosowanie przemocy, niekiedy z bronią w ręku, w różnych sytuacjach. Popełnianie takich czynów ściągało na duchownego wspomnianą irregularitas. Prawo kanoniczne nakładało bowiem na kandydatów do kolejnych stopni święceń określone wymagania, np. prawe urodzenie, nieskazitelną moralność, dostateczny wiek, brak przywar psychicznych i umysłowych, defektów fizycznych czy też chrześcijańską łagodność (perfecta lenitas). Niespełnienie tych wymogów nazywano w prawie kanonicznym właśnie wadliwością. Uniemożliwiała ona przyjmowanie święceń. Należy wyraźnie podkreślić, że jeżeli wadliwość nastąpiła już po przyjęciu święceń (irregularitas subsequens), to zabronione było wykonywanie czynności wynikających z tych święceń, a także przyjęcie święceń wyższego stopnia. Przyczyny wadliwości wynikały z dwóch powodów: braku określonych przymiotów (irregularitates ex defectu) lub występku (irregularitates ex delicto). Brak łagodności chrześcijańskiej, który ściągał na duchownych irregularitates ex delicto, wynikać mógł m.in. z udziału duchownych w wojnach i posługiwaniu się bronią, co mogło prowadzić do śmierci i kalectwa innych osób, udziału w bójkach, a także uczestnictwa (choćby przez pisanie odpowiednich pism) w działaniach wymiaru sprawiedliwości, którego wyroki niejednokrotnie oznaczały śmierć skazanych. Ściągnięcie na siebie wadliwości z powodu braku perfekcyjnej łagodności (perfecte lenitatis) bardzo często było również wynikiem codziennego życia duchownych, w którym to właśnie oni stawali się uczestnikami rozmaitych sporów, kłótni i konfliktów, często kończących się użyciem broni i rozlewem $\mathrm{krwi}^{20}$.

Ważną sprawą, pozwalającą na lepsze zrozumienie funkcjonowania Penitencjarii Apostolskiej oraz zasad związanych z otrzymywaniem dyspens, jest przedstawienie mechanizmów związanych z obiegiem pism w tym ważnym urzędzie. Po złożeniu i przyjęciu supliki na ręce prokuratora trafiała ona do audytora kolektora, a następnie audytora - znawcy prawa kanonicznego. Decyzję w przedłożonych sprawach podejmował kardynał penitencjarz albo regens, wyrażając swoją wolę na podstawie określonych reguł i potwierdzając ją podpisem. Taka zatwierdzona prośba była następnie

18 Zob. K. Salone n, The Penitentiary, s. 160-161; K. Salone n, L. S chmugge, A Sip, s. 44; P. S te c zk ow s ki, Penitencjaria, s. 109-111.

${ }_{19}$ K. S a lon e n, L. S c h mugge, A Sip, s. 114 n.; P. S te c zk ow s ki, Penitencjaria, s. 103.

${ }^{20}$ P. H in s c hi u s, Das Kirchenrecht der Katholiken und Protestanten in Deutschland, t. I-VI, Berlin 1869-1897, tu t. I, s. 26 n., t. V, s. 264-266; Encyklopedia kościelna, wyd. M. Nowodworski, t. I-XXXII, Warszawa-Płock 1873-1913, tu t. VIII, s. 300; E. R it t n e r, Prawo kościelne katolickie, t. I-II, Lwów 1907, tu t. I, s. 108-119; zob. też W. Ü 1 h o f, Irregularität, w: Lexicon für Theologie und Kirche, t. V, Freiburg im Breisgau 1960, kol. 766-767. 
rejestrowana, czyli kopiowana do rejestru, po czym przekazywana dystrybutorowi. Ten kierował ją do korektora, który na podstawie otrzymanego pisma sporządzał koncept właściwego dokumentu dyspensy. Następnie pisarz Penitencjarii sporządzał czystopis, który raz jeszcze był sprawdzany pod względem zgodności z prawem przez audytora. W dalszej kolejności taki dokument otrzymywał od datariusza datę i był przekazywany taksatorowi w celu określenia wysokości należnej opłaty. W końcowej fazie sygillator przystawiał pieczęć, a następnie była uiszczana opłata. Po wykonaniu tych czynności dokument był przekazywany petentowi osobiście, względnie osobie go reprezentującej ${ }^{21}$. Wspomniane opłaty były określane w specjalnych taryfikatorach, które zatwierdzał papież. Pierwszy taki taryfikator pochodzi z czasów papieża Benedykta XII z 1338 r. ${ }^{22}$ Były one relatywnie niskie w stosunku do dochodów uzyskiwanych przez wielu duchownych z ich beneficjów ${ }^{23}$. Należy zwrócić uwagę, że supliki w Penitencjarii można było przedłożyć osobiście lub poprzez inną osobę. Takie osobiste stawiennictwo mogło mieć na celu jak najszybsze załatwienie sprawy. W przypadku polskiego duchowieństwa takie przypadki były jednak stosunkowo rzadkie. Osobiście suplikę złożył np. Stanisław syn Nasięgniewa ze Szczawina, archidiakon dobrzyński i kanonik płocki, na co wskazuje dokument z 20 VIII 1401 r., w którym czytamy: In nostra personaliter constitutus praesentia exposuisti. Duchowny ten śmiertelnie ranił pewnego chłopa w płockiej karczmie, stając w obronie swojego krewnego, którego ów chłop próbował zabić24.

Średniowieczne duchowieństwo stanowiło grupę społeczno-zawodową, która podlegała własnemu sądownictwu, opartemu, zgodnie z uzyskanym privilegium fori, na prawie kanonicznym ${ }^{25}$. Za złamanie tego prawa duchowni byli karani na szczeblu diecezji, względnie musieli się ubiegać o wspomniane dyspensy papieskie, związane $\mathrm{z}$ posiadaną przez papieża plenitudo potestatis ${ }^{26}$. Równocześnie jednak duchowni, szczególnie niższego szczebla, żyli w określonych środowiskach społecznych, zwykle wiejskich lub małomiasteczkowych, i musieli się dostosowywać do zasad w nich obowiązujących ${ }^{27}$. Nie należy zatem szczególnie się dziwić, że spokój w przestrzeni społecznej przywracali z siłą i przymusem. Następowało to jednak zgodnie z obowiązującą zasadą prawa kanonicznego, znaną z Dekretałów Grzegorza IX i eksponowaną $\mathrm{w}$ wielu dokumentach dyspens: vim vi repellendo et se defendendo ${ }^{28}$. Spokój duszy

${ }^{21}$ Procedury te omawiają K. S a l o n e n, L. S c h m u g g e, A Sip, s. 69-83; P. S te c zk ow s ki, Penitencjaria, s. 118-139.

${ }^{22}$ H. D e n i fl e, Die älteste Taxrolle der apostolischen Pönitentiarie, Archiv für Literaturund Kirchengeschichte des Mittelalters 4, 1888, s. 220-236.

${ }^{23} \mathrm{Na}$ ten temat obszernie W. P. M üller, The price of papal pardon - new fifteenthcentury evidence, w: Päpste, Pilger, Pönitentiarie. Festschrift für Ludwig Schmugge zum 65. Geburtstag, Tübingen 2004, s. 457-482; w literaturze polskiej krótko P. S te c z k o w s ki, Penitencjaria, s. 136-139.

${ }^{24}$ BP III, nr 781. Szerzej: A. R a d z i m iń s k i, Z życia codziennego.

${ }_{25}$ Zob. np. W. A b r a h a m, Privilegium fori duchowieństwa w ustawodawstwie Kościoła polskiego w XIII w., Lwów 1936.

${ }_{26}$ Na temat plenitudo potestatis papieży zob. P. S t e c z k o w s k i, Penitencjaria, s. 39-52.

27 Zob. Obyczaje w Polsce, s. 94-95.

28 Zob. Dekretały Grzegorza IX, lib. V, tit. XII (De homicidio voluntario vel casuali) Corpus iuris canonici, t. II, wyd. Ae. Friedberg, Graz 1959, kol. 793-804. 
i postawę zgodną z prawem kanonicznym w takich sprawach duchowni przywracali sobie przede wszystkim za pomocą wspomnianych już dyspens de diversis formis. Uważam, iż często traktowali je bardzo pragmatycznie, jako niezbędny krok do uzyskania kolejnego stopnia święceń, a w konsekwencji objęcia konkretnego beneficjum, do czego święcenia te były niezbędne. Czynili tak również, by nie stracić posiadanego już stanowiska i płynących z niego dochodów ${ }^{29}$. W tym miejscu omówię i zinterpretuję z punktu widzenia prawa kanonicznego dyspensy, które dodatkowo pokazują sytuacje (niekiedy barwne), które zmusiły duchownych do starań o ich uzyskanie. Zwrócę przy tym uwagę na prawne różnice występujące między tymi dyspensami oraz na świadomość prawną składających je duchownych. Rozpocznijmy od przykładów odnoszących się do życia codziennego i dramatycznych sytuacji, jakich doświadczyli duchowni, a które zdarzały się we wsi, karczmie, klasztorze, szkole czy kancelarii.

Przedstawione poniżej supliki polskich duchownych wskazują na trudne niekiedy życie duchownych w lokalnych społecznościach. Suplika Stanisława Trojana rektora kościoła parafialnego w Długiej Dąbrowie w diecezji łuckiej z 21 II 1467 r. opisuje sytuację, gdy to pewnej niedzieli wieczorem przebywał on na plebanii ze swoimi przyjaciółmi, gdy dotarła do niego wiadomość, że do jego domu zamierzają przybyć pewni ludzie, aby go pobić, a nawet zabić. Po wieczornym posiłku opuścił on więc wraz z przyjaciółmi dom. Dostrzegł wówczas swoich nieprzyjaciół, którzy z bronią w rękach weszli już na cmentarz przykościelny. Okazało się, że już wcześniej pobili oni duchownemu psa, który służył do ochrony domu, a następnie uwięzili i pobili scholara oraz służącego. Kiedy Stanisław zażądał, aby nieprzyjaciele pozostawili go w spokoju, oni rzucili się na niego gwałtownie, próbując go zabić. Wówczas duchowny, stosując wspomnianą już prawną zasadę vim vi repellendo et se defendendo, uderzył włócznią jednego z napastników, raniąc go śmiertelnie. Na końcu supliki znalazły się, mające jednak charakter formularzowy, wątpliwości duchownego, czy rzeczywiście był on winny zabójstwa i tym samym ściągnął na siebie stosowną wadliwość, z powodu której nie mógłby wykonywać czynności kapłańskich. Zauważmy, że duchowny ten był zmuszony wystąpić o taką dyspensę, gdyż w przeciwnym wypadku groziłaby mu utrata beneficjum plebańskiego. W jego wypadku miała miejsce klasyczna irregularitas subsequens. Dodajmy ponadto, że dyspensa ta miała charakter komisaryczny. W końcowej sekwencji znajdujemy bowiem zapis skierowany do miejscowego biskupa, aby ten stwierdził na miejscu, czy przedstawiona w suplice sytuacja odpowiadała rzeczywistości. Jej treść brzmi następująco: Committatur ordinario et si vocatis vocandis sibi constiterit, quod exponens vim vi repellendo et se deffendendo alias fugere, vel evadere non valens percussit, ut praefertur et de aliis expositis declaret ${ }^{30}$.

Wśród dyspens de diversis formis szczególnie ciekawe były takie, w których duchowni zwracali się o uwolnienie od podejrzeń o popełnienie zabójstwa (czy szerzej - rozlewu krwi), co mogło ściągnąć na nich ekskomunikę lub irregularitas, a w konsekwencji pozbawić ich prawa wykonywania funkcji kościelnych oraz

${ }^{29}$ Szerzej zob. A. Radzimiński, Dispensen; P. S te c zkowski, Penitencjaria, s. 111-113.

${ }^{30}$ BP VII, nr 370. 
dochodów. Zabiegający o pozytywną decyzję w danej sprawie musiał udowodnić, że okoliczności zajścia wyłączały jego winę. Wszelkie wątpliwości powodowały, że Penitencjaria wydawała dyspensę o charakterze komisarycznym, polecając biskupowi diecezjalnemu sprawdzenie stanu faktycznego w danej sprawie. Wspomniałem już, że w prawie kanonicznym ważną okolicznością łagodzącą była obrona konieczna. Trzeba było jednak udowodnić, że nie przekroczyło się jej granic. Ponieważ duchownych obwiązywał zakaz noszenia broni, z wyjątkiem małego noża, trudno się dziwić, że gdy duchowny powoływał się w swej suplice na obronę własną, dodawał zwykle, że zadał jeden tylko cios, i to małym nożem, ewentualnie małą siekierką lub toporkiem. Taką właśnie sytuację opisał w swojej suplice z 22 VIII 1469 r. Mikołaj Crucsznert kapłan diecezji włocławskiej. Dramatyzmu całej sytuacji dodają zamieszczone w tym dokumencie dialogi. Pewnego dnia napotkany przez niego Maciej Rassus przywitał go słowami groźby: Volo te interficere i wyjętym z pochwy mieczem, którym natychmiast go zranił. Mikołaj nie miał innego wyboru, jak kontratakować: Videns autem ipse exponens se aliter mortem evitare et manus dicti laici effugere non posse, vim vi repellendo et se defendendo prefatum laicum cum quodam parva securi, quam tenebat in manibus, percussit et vulneravit, ex quibus percussione et vulneribus diem suum clausit extremum. Ponieważ Mikołaj chciał uniknąć grożącej mu wadliwości, zwrócił się do Penitencjarii o stosowną dyspensę. Z uwagi na opisane okoliczności również i tu zastosowano tryb komisaryczny ${ }^{31}$. Wątki związane z używaniem przez duchownych jedynie małych noży lub (jak w opisanym przykładzie) siekierek będą stosunkowo często występowały w interesujących nas tekstach. Możemy uznać to za twierdzenia prawdziwe, wskazujące na ścisłe podporządkowanie się przez duchownych przepisom prawa kanonicznego lub swego rodzaju toposy. W dokumentach dyspens udzielanych przez Penitencjarię, które wydano w związku z sytuacjami konfliktowymi, zwłaszcza pobiciami, zranieniami i bójkami, znajdujemy liczne informacje o używaniu przez duchownych małych noży, małych siekierek czy małych włóczni itp., względnie uderzania tymi lub innymi przedmiotami (np. kijem) jedynie lekko, względnie tylko jeden raz. Duchowni mogli oczywiście stosować taką formułę ze świadomością, że tylko na posiadanie takich noży zezwalał prawo. Mam jednak wrażenie, że stosując tego typu formułę, starali się niekiedy dodatkowo usprawiedliwić swoje postępowanie niezgodne z moralnością i kanonami. Nie wydaje się zatem, aby tego rodzaju określenia można było zawsze traktować jako w pełni odzwierciedlające rzeczywistość. Popatrzmy na kilka przykładów. Paweł syn Andrzeja ze Skalbmierza, kleryk diecezji krakowskiej, zranił w bójce Wawrzyńca ze Skalbmierza kijem lekko w głowę (cum quodam ligno leviter percusisti). Z kolei jego krewny uderzył owego Wawrzyńca w pierś małą włócznią (cum parva lancea) ${ }^{32}$. Dominik Schampe kapłan diecezji ozylskiej w trakcie bójki w karczmie z Jakubem familiarisem i kucharzem biskupa ozylskiego uderzył go małym nożykiem (parvum cultellum) ${ }^{33}$. Z kolei wspomniany już Mikołaj Crucsznyert kapłan diecezji włocławskiej, wdając się w bójkę z Maciejem zw. Rassus, zaatakował go małą siekierką (cum quodam parva

${ }^{31}$ BP VII, nr 745. Zob. K. S a lo n e n, L. S c h mugge, A Sip, s. 53; P. S te c z k ow s k i, Penitencjaria, s. 111-113.

32 BP III, nr 867 (9 I 1403).

33 BP VII, nr 406 (29 IV 1467). 
securi $)^{34}$. Jan syn Stanisława z Litwy, kapłan diecezji wileńskiej, pewną nieposłuszną służącą uderzył, jak napisał, lekko kijem (cum quodam ligno - - leviter percussit) ${ }^{35}$. Takich przykładów możemy oczywiście znaleźć znacznie więcej.

Trudne relacje duchownych z lokalną szlachtą obrazuje również suplika Mikołaja syna Jana z Kurowa, akolity diecezji gnieźnieńskiej z 9 X 1464 r. Został on zaproszony przez szlachcica Jana z Jacienina na obiad i kolację. Na kolacji pojawił się niestety także szlachcic Maciej Civninstzy wraz ze swoimi „klientami”, którzy czekali przed domem. Prosił on gospodarza o wydanie Mikołaja, gdyż chce go zabić. Kiedy usłyszał odmowę, wraz ze swoimi ludźmi wyrwał drzwi do domu i poranił rodzinę gospodarza. Mikołaj uciekł, został jednak ostatecznie schwytany przez Macieja i zraniony mieczem w twarz. Odwzajemnił się podobnym uderzeniem, które jednak spowodowało śmierć Macieja. Należy podkreślić, że udzielona dyspensa miała także charakter komisaryczny i stworzyła Mikołajowi możliwość sprawowania obowiązków wynikających z posiadania święceń akolitatu oraz przyjęcia dalszych święceń ${ }^{36}$. Podobnie złożone relacje $\mathrm{z}$ lokalną szlachtą opisane zostały w suplice Wincentego syna Tomisława z Sierakowa, archidiakona uniejowskiego z 26 V 1411 r. Dowiadujemy się z niej, że pewnego dnia udał się do taberny w Radomsku, gdzie było wielu pijanych. Gospodarz okazał gościowi, jako wyższemu duchownemu, odpowiedni szacunek na powitanie. Gest ten nie spodobał się jednak innym obecnym, jak należy sądzić z poniższego tekstu - szlacheckiego pochodzenia, którzy mieli powiedzieć owemu gospodarzowi: Quare tantam reverentiam tu exhibes, iste nunquid melioris conditionis est, quam nos sumus. Wincenty, mając poczucie własnej wartości i znaczenia, odpowiedział w te słowa: Amici, non curetis, quis ego sum, sed sedeatis quieti et simus boni socii, quia ego in isto hospitio etiam nocte praeterita dormivi et equum meum et alias res hic habeo. Quia si sciretis, quis ego sum, mihi etiam reverentiam exhiberetis, sicut facit et fecit hospes ipse. Ta wypowiedź tak wzburzyła pijanych, że ruszyli na niego z mieczami w rękach. Wówczas gospodarz stanął między nimi, pewien kapłan zaś, przyjaciel Wincentego, widząc zagrożenie jego życia, sprowadził pomoc. Po jej przybyciu Wincenty zachował się po chrześcijańsku i nakazał, aby nie zabijać pijanych, a tylko ich ukarać, aby wiedzieli, z kim mają do czynienia. Kiedy bowiem doszło do walki, miał powiedzieć jednemu z przyjaciół: Amice, non occidas, sed corrigas eum. Przeciwnicy jednak ranili się nawzajem. Sam Wincenty również zranił jednego z napastników w nogę. Choć obyło się bez rozlewu krwi (tamen absque aliqua sanguinis effusione), zraniony zmarł niestety po tygodniu ${ }^{37}$. Decyzja Penitencjarii pozwoliła Wincentemu na przyjęcie wyższych święceń subdiakonatu i diakonatu, utrzymanie posiadanego beneficjum archidiakona, a także obejmowanie w przyszłości innych beneficjów.

Wspomniałem już, że do kompetencji Penitencjarii należało uwalnianie od ekskomuniki mnichów lub mniszki, którzy zdecydowali się na opuszczenie klasztoru. Udzielano wówczas dyspens, które również należały do kategorii de diversis

34 BP VII, nr 745 (22 VIII 1469).

${ }^{35}$ BP IV, nr 1920 (20 III 1427).

${ }^{36}$ BP VII, nr 12 (et eum ad omnes etiam sacros presbiteratus ord. promoveri et in ipsis postquam promotus fuerit libere et licite ministrari posse).

${ }^{37}$ BP III, nr 1304. 
formis. Porzucenie życia klasztornego nazywano apostazją i czyn ten od $1298 \mathrm{r}$. był zagrożony karą ekskomuniki latae sententiae, którą zaciągało się przez sam fakt popełnienia przestępstwa, a która nie wymagała przeprowadzania żadnego postępowania $^{38}$. Dyspensy udzielano ponadto osobom, które zrezygnowały z samego zobowiązania do prowadzenia życia zakonnego ${ }^{39}$. Okoliczności uzyskania dyspensy w tej drugiej sprawie opisał Jan Lobaw kapłan diecezji włocławskiej w suplice z 23 II 1467 r. Będąc mianowicie, jak napisał, bardzo pobożny, wstąpił do klasztoru kartuzów w Kartuzach (Paradisus Beatae Mariae) w archidiakonacie pomorskim diecezji włocławskiej i przywdział habit nowicjusza, który nosił przez kilka miesięcy. Choć nie złożył jeszcze profesji, to jednak zobowiązał się do życia zakonnego. $\mathrm{W}$ związku z pojawieniem się w klasztorze pewnej choroby, która również jemu mogła przynieść uszczerbek na zdrowiu, postanowił go opuścić i powrócić do stanu świeckiego. Dowiedział się jednak, że w związku z tym musi zabiegać o dyspensę, i dlatego zwrócił się o nią do Penitencjarii. Dodajmy jeszcze, że również i ta dyspensa miała charakter komisaryczny ${ }^{40}$. Życia klasztornego, a raczej używania przemocy w klasztorze, dotyczy kolejna dyspensa, która - z uwagi na okoliczności - również miała charakter komisaryczny ${ }^{41}$. W suplice z 15 IX 1467 r. Piotr syn Klemensa, profes klasztoru franciszkanów w Obornikach w diecezji poznańskiej, opisał pewną konfliktową sytuację, która rozpoczęła się w karczmie, a skończyła bójką w klasztorze. Pewnego dnia wraz z gwardianem oraz dwoma innymi zakonnikami tego konwentu Piotr spożywał wspólny posiłek w tabernie znajdującej się obok klasztoru. $\mathrm{W}$ trakcie tego posiłku miało zostać wypowiedzianych przez gwardiana i owych współbraci wiele słów obelżywych. Spowodowało to, że wspomniani zakonnicy poruszeni gniewem powrócili do klasztoru. Po pewnym czasie powrócił również Piotr. Kiedy pojawił się w sypialni, gdzie było ciemno, dwaj zakonnicy oczekujący na gwardiana pomyśleli, że to właśnie on nadchodzi, i zaatakowali Piotra, a jeden z nich rzucił kamieniem w jego stronę. Gdy Piotr się odezwał: Quid vobis feci?, tamci odpowiedzieli: Parcas nobis frater, quia non te noveramus. Wówczas Piotr ostrzegł ich, że jeśli osobą, na którą czekają, jest gwardian, to natychmiast zostaną usunięci z klasztoru. Słysząc to, uderzyli Piotra wielokrotnie pięściami. Przybyły gwardian nakazał im zaprzestać, ale Piotr postanowił jednak uciekać i wówczas został przez jednego z napastników zaatakowany żelaznymi widłami. W obronie własnej skierował owe widły tak, że uderzyły w głowę napastnika, aczkolwiek nie polała się krew. Trafionego w ten sposób konfratra przeniesiono do łaźni, gdzie z powodu złej opieki zmarł po pięciu dniach. W końcowej sekwencji dyspensy o charakterze komisarycznym znalazła się informacja skierowana do biskupa diecezjalnego, aby sprawdził prawdziwość tej wersji ${ }^{42}$. Warto zwrócić uwagę, że wydawanie dyspens

${ }^{38}$ B. Woj c i e c how s k a, Ekskomunika w Polsce średniowiecznej. Normy i funkcjonowanie, Kielce 2010, s. 108.

${ }^{39}$ K. S a l o n e n, L. S c h mugge, A Sip, s. 32-33; P. S te c z k ow s ki, Penitencjaria, s. $104,107$.

${ }^{40}$ BP VII, nr 371.

${ }^{41}$ K. Salon en, L. S c h mugge, A Sip, s. 70-74; P. S te c z k ow s ki, Penitencjaria, s. 120.

${ }^{42}$ BP VII, nr 468. 
komisarycznych w skomplikowanych sprawach wskazuje wyraźnie, że Penitencjaria podchodziła z należytym dystansem do treści zawartych w suplikach.

Okazuje się, że również kontakt ze szkołą, zarówno dla nauczycieli, jak i uczniów, prowadzić mógł niekiedy do sytuacji konfliktowych, względnie do przypadkowych wypadków, które wymagały stosownej dyspensy. Poniższy przykład, może nieco komiczny w swojej wymowie, zakończył się jednak tragicznie. Pokazuje on zwykłą sytuację dnia codziennego, która jednak przyczyniła się do śmierci młodego scholara. Dramatyzmu sytuacji opisanej w suplice z 26 I 1470 r. dodają zamieszczone w niej dialogi. Sędziwój z Soboty herbu Nałęcz, rektor kościoła parafialnego św. Marii Magdaleny w Poznaniu i późniejszy kanonik poznański, nabawił się bólu brzucha, co spowodowało, że udał się do ustępu, określonego jako cloaca [que] vulgariter dicitur seckret ${ }^{43}$. W birecie miał ukryty swój testament, który pechowo wpadł do wspomnianej kloaki. Sędziwój wezwał wówczas pewnego świeckiego, aby ten wyciągnął mu wspomniany testament. Wezwany odmówił, proponując, aby wziąć do pomocy jakiegoś młodszego scholara, który za pomocą drabiny mógłby zejść i łatwo wyciągnąć dokument. Sędziwój wezwał więc jednego ze scholarów, który zszedł do kloaki. Zaraz jednak zaczął głośno wołać: Hic maximus fetor est. Sędziwój, śmiejąc się, polecił mu: Benefrater, attingas instrumentum antedictum. Scholar cofnął się jednak, skarżąc się ponownie: Ve mihi, maximus fetor. Wspomniany świecki ponaglił go: Extrahe citius eandem litteram, ale było już jednak za późno. Chłopak z pewnością zatruł się kloacznymi oparami i został wyciągnięty nieżywy. Przyznana dyspensa zwalniała Sędziwoja od winy za śmierć scholara, a ponadto zezwalała mu na zachowanie wspomnianych beneficjów kościelnych, a do tego jeszcze kanonii w kolegiacie św. Jerzego w Gnieźnie ${ }^{44}$.

W szkole występowały niekiedy także konflikty między uczniami i nauczycielami. Jeden z takich sporów opisują dwie supliki Mikołaja syna Hermana z Lubicza, rektora miejskiej szkoły w Toruniu z 1418 i 1420 r. Jego konflikt z jednym z uczniów zakończył się ostatecznie śmiercią tego ostatniego. Dyspensa uwalniała rektora od ekskomuniki oraz innych kar, a także wadliwości, co spowodowało, że mógł nadal wykonywać dotychczasowe obowiązki wynikające z niższych święceń, które wówczas posiadał. Ponadto dyspensa dawała mu prawo do uzyskania wyższych święceń oraz obejmowania beneficjów ${ }^{45}$. Na szkołę warto spojrzeć również przez pryzmat problemów, jakie opiekunom sprawiali ich młodzi podopieczni. Bardzo ciekawy przykład opisuje suplika Sobiesława syna Dobiesława z Drochowa, kleryka diecezji płockiej z 13 IV 1391 r. Opiekował się on mianowicie dość niesfornym bratankiem w szkole kształcącej na poziomie trivium. Chłopiec ciągle uciekał ze szkoły, Sobiesław zaś usiłował go przekonać do zmiany postępowania. Bił go w związku z tym

${ }^{43}$ Ostatnio P. D e m b i ń s k i, Poznańska kapituła katedralna schyłku wieków średnich. Studium prozopograficzne 1428-1500, Poznań 2012, s. 642-644.

${ }^{44}$ BP VII, nr 771; zob. A. R a d z i m i ń s k i, Dispensen, s. 282-283.

${ }^{45}$ BP IV, nr 193 (Sup., ut ipse ab omnibus excommunicationum et aliis sententiis et poenis absolvantur, secumque, qui in minoribus ordinibus dumtaxat constitutus est et in ipsis ministrando et alias divinis se immiscendo super irregularitate contracta ex inde et quod ad omnes sacros ordines ulterius promoveri et beneficia recipere valeat, dispensetur. Fiat), 618; szerzej A. R a d z i m iń s k i, „....super irregularitate”, s. 123-124. 
często rózgami. Po kolejnym takim skarceniu u chłopca wystąpiło krwawienie i po kilku dniach znalazł się w szpitalu. Gdy Sobiesław chciał go przenieść i ułożyć na ziemi, przypadkowo - jak twierdzi - złamał mu rękę. Ostatecznie chłopiec zmarł po ośmiu dniach. Dyspensa uwolniła duchownego od wadliwości i spowodowała, że jeszcze tego samego dnia otrzymał on ekspektatywę papieską na beneficjum znajdujące się w dyspozycji kapituły płockiej ${ }^{46}$. W szkołach dochodziło także niekiedy do konfliktów między samymi uczniami. Ilustruje to suplika Wawrzyńca z Buska, akolity diecezji krakowskiej z 11 I 1466 r. Wszystko wskazuje na to, że uczniowie w szkole, do której chodził, byli podzieleni na dwie grupy: jego przyjaciół i sprzymierzeńców oraz jego przeciwników. Zdaje się, że obie grupy dość często obrzucały się obelżywymi słowami. Przeciwnicy zaczęli się przygotowywać do tego, aby pobić Wawrzyńca i jego towarzyszy. Pewnej nocy weszli do szkoły i znów zaczęli znieważać adwersarzy. Wówczas Wawrzyniec wezwał nauczyciela, aby zaprowadził spokój. Usłyszawszy to, jeden z napastników uderzył trzymanym w ręku kluczem jednego z popleczników Wawrzyńca w głowę i zranił go. Zapewne z tego właśnie powodu uczeń ten wkrótce zmarł. Wawrzyniec nie czuł się winny śmierci wspomnianego scholara, miał jednak wątpliwości, czy nie ściągnął na siebie stosownej wadliwości. Uzyskanie dyspensy (znów komisarycznej) pozwalało mu na sprawowanie nadal funkcji akolity, a w przyszłości - na przyjęcie wyższych święceń ${ }^{47}$.

Duchowni właściwie nie mieli możliwości ustrzeżenia się od irregularitatis, wykonując, wydawałoby się spokojną, pracę w różnych kancelariach, i to nawet wówczas, kiedy mieli głęboką świadomość prawną konsekwencji swojego postępowania. Taką właśnie świadomość prawną dobrze ilustrują dwie supliki Erazma de Frankenaw (Brąchnowo), kleryka diecezji chełmińskiej z 19 IV 1429 i 10 VI 1430 r. ${ }^{48}$ Był on pisarzem w kancelarii komtura tucholskiego Josta von Hohenkirchena i w związku z wojnami Polski i Litwy z zakonem krzyżackim pisał liczne litteras avisatorias, czyli listy wzywające rycerstwo do udziału w wojnie. Musiał też czytać listy, w których proszono komtura o schwytanie złodziei. Erazm zatem doskonale znał przepisy prawa kanonicznego w tym zakresie i rozumiał, że pisanie i czytanie listów, których konsekwencją będzie śmierć lub kalectwo innych osób, ściągnie na niego odpowiednią wadliwość. Napisał on w swojej suplice, że kiedy pewnego razu, wykazując należytą czujność, odmówił napisania listu w celu pochwycenia pewnego podpalacza, to mimo wszystko wyłudzono od niego wosk do opieczętowania pisma, na podstawie którego podpalacz został złapany i zgładzony. Erazm uważał zatem, że powinien wystąpić o papieską dyspensę, ponieważ zamierzał przyjąć wyższe święcenia ${ }^{49}$. Oczywiście duchownych pisarzy lub notariuszy, którzy pisali listy wypowiadające wojny (litteras diffidatorias), wzywające rycerstwo na wyprawę (litteras avisatorias)

${ }^{46}$ BP III, nr 210-211.

${ }^{47}$ BP VII, nr 232; analogiczne przykłady: BP V, nr 479, VII, nr 63, 64, 453.

${ }^{48}$ BP IV, nr 2273, 2470; zob. A. R a d z i m i ń s k i, Dispensen, s. 283.

49 Jost von Hohenkirchen był komturem tucholskim w 1. 1423-1431, Erazm de Frankenaw jest zaś najpewniej identyczny z kapłanem krzyżackim Erazmem, dwukrotnie (11 VI i 21 IX 1430 r.) świadczącym w dokumentach wspomnianego komtura (Urkunden der Komturei Tuchel, wyd. P. Panske, Danzig 1911, nr 135-136); zob. P. T h i e l e n, Die Verwaltung des Ordensstaates Preussen, Köln-Graz 1965, s. 175. 
czy ścigające złodziei i innych przestępców, którym groziła kara śmierci, było znacznie więcej ${ }^{50}$. Praca w kancelarii wiązała się zatem z poważnym ryzykiem popadnięcia w irregularitas i koniecznością starania się o dyspensę w Penitencjarii Apostolskiej. Średniowieczne duchowieństwo brało jednak także osobisty udział w konfliktach zbrojnych. Omawiałem już we wcześniejszej pracy przykład Zbigniewa Oleśnickiego, który w bitwie pod Grunwaldem powalił kopią rycerza miśnieńskiego Dypolda von Kökritza, ściągając na siebie irregularitas super defectu perfectae lenitastis. Interesujące w tym przypadku jest jednak to, że po stosowną dyspensę wystąpił dopiero 13 lat później, 1 VII 1423 r., kiedy został wybrany na biskupa krakowskiego. Należy wyraźnie podkreślić, że Oleśnicki posiadał w momencie popełnienia wspomnianego czynu niższe święcenia. Konsekwencją zaś jego popełnienia było bez wątpienia zaciągnięcie przez niego wadliwości w wykonywaniu wynikających z nich czynności. Wydana 13 lat po wydarzeniach dyspensa w końcowej klauzuli wyraźnie stwierdza, że uwolniono Zbigniewa od wadliwości w związku z posiadanymi niższymi święceniami oraz zezwolono mu na przyjęcie święceń wyższych oraz godności biskupiej ${ }^{51}$. Jest oczywiście możliwe, że Zbigniew Oleśnicki nie wykonywał przez 13 lat czynności wynikających z posiadanych przez niego niższych święceń. Należy jednak pamiętać, że posiadał on w tym czasie kilka ważnych beneficjów kościelnych. Osobiście widziałbym w jego przypadku dość instrumentalne podejście do norm prawa kanonicznego. Trzeba przyznać, że w pierwszej połowie XV w. wielu duchownych uwikłanych było w wojny polsko-krzyżackie. Michał syn Szymona z Boryszewa, kanonik płocki i prepozyt kolegiaty św. Michała w Płocku, jako notariusz księcia mazowieckiego Siemowita IV wziął $\mathrm{z}$ jego polecenia udział w wyprawie do Prus ${ }^{52}$. Z kolei Jan syn Stanisława $\mathrm{z}$ wielkopolskich Bogucic brał udział w działaniach zbrojnych prowadzonych przez polskiego króla przeciwko zakonowi krzyżackiemu, w których plures homines interficiebantur, choć on sam, jak podał w suplice, nikogo nie zabił ani nie zrani ${ }^{53}$. W wielkiej wojnie z Zakonem aktywnie brał udział Marcin syn Przybysława z Płońska, kapłan diecezji płockiej, który broniąc jednego z zamków na Mazowszu, użył małej bombardy i wystrzelił do nieprzyjaciół, trafiając kamieniem jednego $\mathrm{z}$ nich w obie nogi. Pomógł też pewnemu świeckiemu wnieść na wieżę bombardę, z której zabito potem jednego z przeciwników. Dodajmy również, że w trakcie walk Marcin sam został ranny ${ }^{54}$. Kolejny przykład pochodzi z supliki Wincentego Eckego, duchownego diecezji chełmińskiej i stronnika Krzyżaków, datowanej na 18 V 1411 r. $\mathrm{Na}$ początku ujawnił on, że jego matka, kiedy jeszcze nosiła dziecko w brzuchu,

${ }^{50}$ BP VII, nr 129 (Jerzy syn Świętosława z Malewa, akolita diecezji płockiej, pisarz pewnego pana świeckiego), 362 (Jan syn Macieja Nyechotez, akolita diecezji krakowskiej), 394 (Burchard z Siedlątkowa kleryk diecezji gnieźnieńskiej, notariusz starosty łęczyckiego Mikołaja z Kobyłek), 484 (Stanisław syn Wojciecha kleryk diecezji gnieźnieńskiej).

${ }^{51} \mathrm{BP}$ IV, nr 1175 (absolvimus et nihilominus tecum super irregularitate, si quam praemissorum occasione contraxisti, et quod in susceptis ordinibus ministrare, nec non ad omnes $s$. ordines promoveri et ad dignitates quascumque, etiam archiepiscopales et episcopales promoveri - - valeas, - - dispensamus); szerzej A. R a d z i m i ń s k i, ,...super irregularitate", s. 116-117.

52 BP IV, nr 1877; szerzej A. R a d z i miń s k i, „....super irregularitate”, s. 117-118.

53 BP IV, nr 2311; szerzej A. R a d z i m iń s k i, ,... super irregularitate”, s. 118-119.

${ }^{54}$ BP III, nr 1301. 
poprzysięgła sobie, że jeżeli urodzi się chłopiec, to zostanie kapłanem. W związku z tym posłano go na studia na uniwersytecie w Pradze. W odniesieniu do swojej sprawy napisał, że w czasie wielkiej wojny Polski i Litwy z Zakonem Krzyżackim nosił broń i wraz z mieszkańcami Grudziądza ścigał Polaków, którzy ukradli bydło. Niektórzy z napastników zostali wtedy zabici. Sam Wincenty jednak, jak twierdził, nikogo nie zabił ani nie zranił, miał jednak wątpliwości, czy nie wyniknęła $\mathrm{z}$ tego irregularitas ${ }^{55}$. Takich przykładów, gdy duchowni brali udział w konfliktach zbrojnych, zarówno polsko-krzyżackich, jak i innych, znajdziemy znacznie więcej. Pokazują one te wojny w ludzkiej mikroskali, często w ciekawy sposób opisując szczegóły ich przebiegu ${ }^{56}$. Wskazują ponadto na fakt, że duchowni ci dobrze znali przepisy prawa kanonicznego i bezpośrednio po zaistniałych wydarzeniach starali się o stosowną dyspensę.

Kobiety, szczególnie anonimowe lub znane tylko z imienia, stosunkowo często pojawiały się wokół duchownych. Powodem nie był jednak wyłącznie konkubinat, ale różne, niekiedy trudne życiowe sprawy, które powodowały, że kobiety stawały na drodze kariery poszczególnych duchownych ${ }^{57}$. Jedną z takich sytuacji opisuje w suplice z 14 III 1466 r. Jan syn Mikołaja z Przełęku, kleryk diecezji gnieźnieńskiej, który bardzo chciał uzyskać wyższe święcenia i zrobić karierę kościelną. Wcześniej jednak wielokrotnie współżył z pewną „nierządnicą”, która w pewnym momencie zaszła w ciążę. Jan nie był jednak pewien, czy to on był rzeczywiście ojcem przyszłego dziecka. Niestety po urodzeniu się chłopca wspomniana kobieta udusiła go bez chrztu, przy czym Jan nie udzielił jej przy tym żadnej pomocy. Warto dodać, że dyspensa miała $w$ tym przypadku także charakter komisaryczny ${ }^{58}$. Z kolei na przeszkodzie zgodnego z prawem wykonywania funkcji kapłańskich przez Pawła syna Arnolda z diecezji włocławskiej stanęła wcześniejsza znajomość z dziewczynką w wieku ok. 8 lat. W suplice z 15 VII 1466 r. pisał on, że swego czasu zaręczył się z nią, jednakże nie współżył z nią cieleśnie ani nie domagał się tego. Później przyjął wyższe święcenia i wykonywał funkcje do nich przynależne, co wymagało jednak stosownej dyspensy ${ }^{59}$. Z tekstu wynika wyraźnie, że duchowny dopiero po

${ }^{55}$ BP III, nr 1302. Zob. A. R a d z i m i ń s k i, Dispensen, s. 280-281. Na temat tej wojny: S. Jóźw i a k, K. Kw i t k o w s ki, A. S zw ed a, S. S z y b k ow s ki, Wojna Polski i Litwy z Zakonem Krzyżackim w latach 1409-1411, Malbork 2010.

${ }^{56} \mathrm{~Np}$. BP V, nr 31 (Mikołaj Walffdorff kleryk diecezji włocławskiej), 272 (Teodoryk Weynrich kleryk diecezji krakowskiej), 476 (Piotr syn Andrzeja, rektor kościoła parafialnego w Słaboszowie w diecezji krakowskiej), 791 (Henryk Deytmar scholar z Bambergu), VII, nr 41 (Piotr ze Strzałkowa kapłan diecezji płockiej, wikariusz w Drobninie), 242 (Jan Wątróbka ze Strzelec prepozyt kolegiaty św. Michała w Krakowie, kanclerz królowej Elżbiety), 290 (Leonard syn Jana ze Sławczyna, rektor kościoła parafialnego w Osieku w diecezji krakowskiej).

57 Zob. A. R a d z i m iń s k i, Kobieta, s. 45-56; t e n ż e, The women, s. 33-53.

58 BP VII, nr 257 (Sed quia olim ipse quandam meretricem pluries actu fornicario carnaliter cognovit, ipsamque, ut ipsa post partum asserebat, impregnaret, ipso tamen ignorante quod ob eodem impregnata fuisset. Et cum ipsa meretrice [!] puerum peperisset, eundem puerum sine baptismo suffocavit, sive interfecit).

${ }_{59}$ BP VII, nr 311 (quod ipse olim cum quadam puelle [!] octo a. vel circa sponsalia per verba de futuro contraxit, carnali copula cum eadem minime subsecuta nec in aliquo accentate se fecit alias tamen rite ad omnes sacros ord. promoveri, ut in illis pluribus ministravit). 
latach przypomniał sobie o konieczności uzyskania stosownej dyspensy. Także za sprawą kobiety i dzieci z nią spłodzonych nieco bardziej skomplikowana okazała się droga do kariery duchownej Szymona syna Jana rzemieślnika, scholara diecezji chełmińskiej. Z jego supliki z 27 III 1468 r. wynika, że pozbawił on dziewictwa pewną kobietę, a następnie zatrzymał przez rok w domu jako konkubinę i spłodził z nią dzieci. Później zawarł z nią legalne małżeństwo, z którego również mieli dzieci. Kobieta ta niestety zmarła, Szymon zaś postanowił przyjąć wyższe święcenia, starając się najpierw uzyskać stosowną dyspensę ${ }^{60}$. Relacje duchownych z kobietami były niekiedy bardzo dramatyczne, szczególnie dla tych ostatnich. Taka sprawa dotyczyła losów konkubiny Stanisława z Dobrzynia kapłana diecezji płockiej, przedstawiona w suplice z 20 III 1441 r. Kobieta ta miała wypowiedzieć przeciwko owemu duchownemu pewne verba iniuriosa, za co Stanisław skarcił ją, uderzając kijem w plecy ${ }^{61}$. Okazało się jednak, że była ona w trzecim miesiącu ciąży, o czym - jak wskazuje kolejny dokument w tej sprawie z 20 IV 1442 r. - nasz duchowny nie wiedział ${ }^{62}$. W następstwie tej sytuacji konkubina udała się do odległej wsi, gdzie poroniła, sama jednak pozostała w dobrym zdrowiu.

Wspomniałem już, że do przestępstw, których popełnienie wymagało uzyskania stosownej dyspensy z kategorii de diversis formis, należały także fałszerstwa. Zdarzało się np. niekiedy, że duchowni przez fałszerstwo próbowali zdobywać poświadczenia gwarancji uzyskania materialnego utrzymania, aby móc otrzymać kolejne święcenia. Posiadanie takich gwarancji wynikało z norm prawa kanonicznego i było warunkiem koniecznym udzielenia święceń ${ }^{63}$. Bartłomiej syn Mikołaja, diakon diecezji poznańskiej, jak wskazuje suplika z 11 VIII 1438 r., sfałszował taki dokument, w którym pewien szlachcic imieniem Przedpełk miał zapewnić mu utrzymanie, aby ten mógł przyjąć święcenia kapłańskie. Takowych wprawdzie ostatecznie nie uzyskał, ale na podstawie sfałszowanego listu został najpierw wyświęcony na subdiakona, a następnie na diakona ${ }^{64}$. Fałszowano także dokumenty poświadczające uzyskanie święceń z rąk biskupa. Wspomina o tym Jakub de Przeluszaby kapłan diecezji poznańskiej w suplice (należącej jednak do kategorii de promotis) z 10 XII 1469 r. Na przyjęcie kolejnych wyższych święceń nie miał on zgody swojego biskupa, więc sfałszował odpowiednie dokumenty poświadczające ich posiadanie. Co więcej, sprawował na tej

60 BP VII, nr 538.

61 BP VII, nr 1064.

62 BP VII, nr 1120 (Et quia exponens omnino ignorabat prefatam mulierem fuisse impregnatam).

63 J. R y b c z y k, Beneficjum, w: Encyklopedia katolicka, t. II, Lublin 1989, kol. 262-265. Na ten temat zob. A. R a d z i m iń s k i, Piętnastowieczny formularz z Uppsali jako źródło do badania Kościoła w państwie zakonu krzyżackiego w Prusach, w: Aetas media, aetas moderna. Księga pamiątkowa Henryka Samsonowicza, Warszawa 2000, s. 239.

${ }^{64} \mathrm{BP} \mathrm{V}, \mathrm{nr} 847$ (ipse olim ad ordinem sacerdotii promoveri desideraret non habens aliquod beneficium sub cuius titulo ordinari possit, quandam litteram aliena manu scriptam fabricatam sub titulo et nomine et sine scitu cuiusdam nob. viri Przedpelk de Cesurim?, ut ad sacros promoveri posset, fieri fecit, in qua canebatur, quod dictus nobilis portionem congruam in victu et vestitu super bonis suis assignabat, licet illud verum non esset. Cuius litterae vigore idem Bartholomaeus ad subdiaconatus et diaconatus ordinem alias tamen rite se promoveri fecit). 
podstawie funkcje kościelne, za co został suspendowany ${ }^{65}$. Niektórzy z duchownych zatem nie tylko posługiwali się fałszywymi dokumentami, które miały poświadczać ich święcenia, ale zdarzało się, że nie mając wyższych święceń, czytali Ewangelię i - co ciekawsze - spowiadali i udzielali rozgrzeszenia. Tak czynił np. Łukasz syn Jana z Chocenia, akolita diecezji włocławskiej, co opisał w suplice z 24 II 1469 r., zakwalifikowanej do kategorii de diversis formis. Stwierdził tam, że nie posiadając odpowiednich święceń, czytał w czasie uroczystych mszy św. listy i Ewangelię oraz słuchał spowiedzi kapłanów, szlachciców i ich żon oraz udzielał im rozgrzeszenia. Dyspensa papieska uwalniała go od suspensy oraz innych grzechów i wadliwości, w które popadł, a także dawała mu możliwość sprawowania funkcji akolity oraz przyjęcia wyższych święceń ${ }^{66}$.

O dyspensy w Penitencjarii Apostolskiej starali się również duchowni, którzy popadli w herezję. Przykładem służy Wincenty kapłan i rektor kościoła parafialnego w Żydowie w diecezji poznańskiej, który został husytą. Napisał on w suplice, że został ukrytym zwolennikiem heretyckiej nauki Jana Husa i nie posłuchał w tej sprawie mandatu papieskiego, który był swego czasu ogłoszony w Pradze. W czasie studiów w Krakowie posiadał księgi i traktaty Husa, których nie chciał oddać nawet na polecenie inkwizytora, biskupa krakowskiego oraz rektora uniwersytetu, przez co ściągnął na siebie ekskomunikę. Mimo tego przyjął święcenia i sprawował wynikające z nich funkcje, celebrując nabożeństwa także w obecności husytów, których powinien wydać władzy duchownej. Dodatkowo popadł więc w wadliwość. Dyspensa, którą uzyskał, uwalniała go od ekskomuniki i wadliwości, a ponadto pozwalała na zachowanie dotychczasowych oraz uzyskiwanie nowych beneficjów ${ }^{67}$.

Wspominałem już, że do dyspens wydawanych przez Penitencjarię Apostolską, rejestrowanych pod nazwą de diversis formis, należały także licencje (zwolnienia od postu, pozwolenia na używanie ołtarza przenośnego itp.). W wydanym materiale źródłowym dla Polski i Litwy dysponujemy kilkoma przykładami pozytywnie zakończonych starań przedstawicieli polskich i litewskich elit o „listy maślane” i „listy mięsne". O taką dyspensę wystąpiła 18 XI 1424 r. szesnastoletnia wówczas Jadwiga, córka Władysława Jagiełły i Anny Cylejskiej. Udzielając zgody, zaznaczono w dokumencie, że spożywanie zabronionej w okresie postu żywności powinno odbywać się za radą medyków ${ }^{68}$. O postne dyspensy dla swoich żon lub dla obojga współmałżonków

${ }^{65}$ BP VII, nr 764 (olim cum quibusdam literis falsis sine licencia sui ordinarii se fecit alias tamen etc. ad omnes sacros ord. promoveri et in ipsis ministravit et alias immiscuit se).

${ }^{66} \mathrm{BP}$ VII, nr 670 (olim tamquam simplex non in contemptum clavium, epistulam, evangeliam in missarum sollempnia pluries sollempniter legit et confessiones XX praesbiterorum et dominorum, mulierum audivit et ipsos a peccatis eorum absolvit).

${ }^{67} \mathrm{BP} \mathrm{V}, \mathrm{nr} 790$ (quod Johannis Huss opinionibus occulte et mente tenus, quantum potuit, adhaerens, mandatis ap. quae tunc in civitate Pragensi publicabantur non parebat librosque et tractatus ipsius Johannis Huss, quos apud se habebat, occultavit, nec eos ad mandatum inquisitoris fidei et episcopi Crac. ac rectoris Universitatis Studii Crac., in qua tunc studebat, qui cum, ut dictos libros sub poenis excummunicationis et iuramenti per eum praestiti exhiberet, generali monitione monuerant, exhibere non curavit sententiam excommunicationis et periurii propter ea incurrendo, qua sic ligatus s. ordines suscepit et in illis ministravit, --ipseque in praesentia Hussitarum scienter celebravit illos iuxta mandatum ordinarii loci et inquisitoris fidei non relevando).

${ }^{68}$ BP IV, nr 1437. 
występowali mężowie. Supliką z 27 VIII 1418 r. wielki książę litewski Witold zwrócił się z prośbą, aby w związku z chorobą, jego żona Anna, córka księcia smoleńskiego Światosława Iwanowicza, mogła w okresie postu spożywać mięso oraz jaja. Dyspensa ta została wydana niestety zbyt późno, gdyż księżna Anna zmarła 31 VII 1418 r. ${ }^{69}$ Natomiast Juliana, druga żona Wojciecha Moniwida herbu Leliwa, wojewody i starosty wileńskiego, córka Dymitra Olgierdowicza starszego, w odpowiedzi na suplikę męża z 11 I 1419 r. uzyskała dla siebie i współmałżonka ad tempora vitae zgodę na spożywanie mięsa w okresie Wielkiego Postu oraz w wigilie świąt ${ }^{70}$.

Warto jeszcze tylko przypomnieć inne kategorie dyspens wydawanych przez Penitencjarię Apostolską. Należały do nich licznie wydawane dyspensy od skutków nieprawego urodzenia (de defectu natalium), a także od innych przeszkód i nieprawidłowości związanych z przyjmowaniem i wykonywaniem święceń (de promotis et promovendis $)^{71}$. Należy bowiem mieć świadomość, że dziecko urodzone z nieprawego łoża nie mogło, bez uzyskania dyspensy, przyjąć święceń ani objąć urzędu kościelnego czy beneficjum ${ }^{72}$. Ludwig Schmugge, znakomity znawca dziejów Penitencjarii papieskiej oraz akt przez nią wytwarzanych, w tym także dyspens de defectu natalium, ustalił, że $60 \%$ ojców starających się o takie dyspensy, które pozwalały na przyjęcie przez synów święceń, a w konsekwencji beneficjów kościelnych, stanowili duchowni, w tym również biskupi. Co więcej, większość tych chłopców urodziła się ze związków tych duchownych z ich gospodyniami ${ }^{73}$. Dysponujemy w tym zakresie także polskimi przykładami. Papież Aleksander IV udzielił 23 III 1254 r. dyspensy magistrowi Gerardowi, diakonowi i kanonikowi krakowskiemu, który był synem kleryka niższych święceń, aby mógł przyjąć święcenia kapłańskie i obejmować beneficja ${ }^{74}$. Przeszkody związane z przyjmowaniem i wykonywaniem święceń obejmowały ponadto brak wymaganego wieku (defectus aetatis), niespełnianie wymogów zdrowotnych (defectus corporis) czy brak podstawowej wiedzy (defectus scientiae) ${ }^{75}$. Wymogów zdrowotnych nie spełniał np. Maciej Sculteti scholar diecezji poznańskiej, starając się w suplice z 24 IX 1467 r. o dyspensę na przyjęcie wyższych święceń. Powodem było uszkodzenie lewego biodra, co zapewne miało wpływ na jego odmienny, rzucający się w oczy, sposób chodzenia ${ }^{76}$. Dyspensa ta została jednak zakwalifikowana do kategorii de diversis formis.

${ }^{69}$ BP IV, nr 327.

${ }^{70}$ BP IV, nr 355; zob. A. K r u p s k a, Moniwid Wojciech, w: Polski słownik biograficzny, t. XXI (1976), s. 658-660.

71 Zob. przykładowe dyspensy z kategorii de defectu natalium (BP VII, nr 241, 733, 753, 835,877 ) oraz de promotis et promovendis (BP VII, $\mathrm{nr} 675,732,764,769$ ).

${ }_{72}$ Szeroko L. S ch mugge, Kirche, Kinder, Karrieren. Päpstliche Dispense von der unehelichen Geburt im Spätmittelalter, Zürich 1995; zob. też P. S t e c z k ow s k i, Penitencjaria, s. 113-114.

${ }_{73}^{73}$ L. S c h m u g g e, Kirche, Kinder, Karrieren, s. 181-188.

${ }^{74}$ BP I, nr 634.

${ }^{75}$ K. S a l o n e n, L. S c h mug ge, A Sip, s. 149-150; P. S t e c z k o w s ki, Penitencjaria, s. $115-116$.

${ }^{76}$ BP VII, nr 499 (ut eo non obstante defectu vasis sinistri sui femuralis possit ad omnes sacros ordines promoveri). 
Penitencjaria Apostolska wydawała ponadto pisma deklaratoryjne (de declaratoriis), które poświadczały np., że dana osoba nie popełniła morderstwa, lub stwierdzały, że nie należy ona do żadnego zakonu, względnie że dane małżeństwo nie jest ważne. Takie pismo deklaratoryjne otrzymał np. 29 VIII 1468 r. wspomniany już Jan de Lobaw kapłan diecezji włocławskiej. Stwierdzało ono, iż duchowny ten nie należy już do zakonu kartuzów, z którego wystąpił, otrzymując później stosowną dyspensę $e^{77}$. Jeszcze innym typem dokumentów, które można było uzyskać w Penitencjarii Apostolskiej, były dwa rodzaje pism spowiedniczych: pierwszy to littera confessionalia in forma minori, zezwalająca na odbycie spowiedzi u dowolnego spowiednika (nie zaś własnego plebana), drugi natomiast to littera confessionalia in forma maiori, upoważniająca spowiedników do absolucji grzechów zarezerwowanych wyższej władzy kościelnej ${ }^{78}$.

W podsumowaniu warto zauważyć, że liczba dyspens de diversis formis, które uzyskiwali polscy duchowni nie jest zbyt wielka, szczególnie w porównaniu ze składanymi do Stolicy Apostolskiej suplikami o beneficja. Inna sprawa, że np. z okresu pontyfikatu papieża Pawła II (1464-1471) najwięcej takich dokumentów dla polskiego duchowieństwa dotyczyło wszelakiego rodzaju bójek z udziałem duchownych. W pewien sposób może to wskazywać także na konfliktowość średniowiecznego społeczeństwa, którego przedstawiciele siłą usiłowali rozwiązywać swe problemy. Wydaje się ponadto, że stosunkowo niewielka liczba takich dyspens wynikała najpewniej z dwóch powodów: słabej znajomości przez duchownych prawa kanonicznego, względnie lekceważenia jego przepisów w kontekście zwykłych wydarzeń dnia codziennego. Wskazałem ponadto także na nieco instrumentalne traktowanie przepisów prawa kanonicznego, tzn. na starania się o dyspensy wówczas, kiedy wiązało się to z poważnym awansem kościelnym, względnie z możliwością utraty beneficjum. Omawiane dyspensy mogą służyć do pogłębionego badania średniowiecznego duchowieństwa jako grupy społeczno-zawodowej. Przede wszystkim dlatego, że nie dysponujemy dla tego okresu źródłami, które by zawierały tak wiele szczegółów z różnych obszarów życia codziennego kleru. Dostrzegamy duchownych najczęściej w życiu lokalnej społeczności, w różnych sporach i konfliktach. Poznajemy przy okazji powody tych konfliktów, często także stosunek świeckich do duchownych, względnie duchownych do siebie nawzajem. W tych lokalnych społecznościach wokół duchownych pojawiają się niejednokrotnie kobiety, jako konkubiny i kochanki, ale też matki ich przyszłych dzieci. Omawiane dyspensy rzucają nieco światła na pracę poszczególnych duchownych w różnych kancelariach i szkołach

77 BP VII, nr 612. W dokumencie tym mowa jest o Jakubie de Lobaw kapłanie diecezji chełmińskiej. Ponieważ opisana jest w nim ta sama sprawa, co w dokumentach z 23 II 1467 i 6 II 1471 r. (tamże, nr 890), gdzie występuje Jan Lobaw (Lobene) kapłan diecezji włocławskiej, należy sądzić, że w piśmie deklaratoryjnym nastąpiła pomyłka w imieniu i w nazwie diecezji; przynależność diecezjalną mógł on teoretycznie zmienić, chociaż ze względu na chronologię pism jest to mało prawdopodobne. Zob. inne dyspensy z tej kategorii: tamże, nr 201, 225, 692, 850 .

${ }^{78}$ Zob. L. S c h mugge, P. Hers perger, B. Wigg e n ha u s er, Suplikenregister der päpstlichen Pönitentiarie aus der Zeit Pius II. (1458-1464), Tübingen 1996, s. 207-217. Przykłady takich dyspens: BP VII, nr 260, 268, 269, 270, 274, 277, 292, 683, 919, 945. 
(zarówno jako młodych scholarów, jak i nauczycieli). Dowiadujemy się o słuchaniu spowiedzi i udzielaniu rozgrzeszenia przez duchownych nieposiadających do tego wymaganych święceń, fałszowaniu dokumentów poświadczających posiadanie odpowiednich święceń. Duchowni brali wreszcie udział w konfliktach zbrojnych, niekiedy także posługując się bronią. Popadali w herezję husycką. Część suplik zawiera do tego bardzo ciekawe, z życia czerpane, dialogi. Licznie zachowane oraz opublikowane przeważnie in extenso dokumenty dyspens Penitencjarii Apostolskiej znacznie wzbogacają materiał źródłowy do dziejów duchowieństwa w Polsce średniowiecznej. Źródła te stanowią znakomitą podstawę do poznania, w jaki sposób duchowni rozumieli przepisy prawa kanonicznego i stosowali się do nich. Mogą być także bardzo przydatne do badań zarówno w zakresie wąsko rozumianej biografistyki, jak również szerzej zakrojonych badań społecznych i średniowiecznej obyczajowości.

\section{BIBLIOGRAFIA}

Abraham W., Privilegium fori duchowieństwa w ustawodawstwie Kościoła polskiego w XIII w., Lwów 1936.

Auctoritate papae. The Church Province of Uppsala and the Apostolic Penitentiary 1410-1526, wyd. S. Risberg, wstęp K. Salonen, Stockholm 2008.

Bullarium Poloniae, wyd. I. Sułkowska-Kuraś, S. Kuraś, t. I-VII, Romae-Lublini 1982-2006.

Clarke P., Central authority and local powers. The Apostolic Penitentiary and the English Church in the fifteenth century, Historical Research 84 (225), 2011.

Corpus iuris canonici, t. II, wyd. Ae. Friedberg, Graz 1959.

Dembiński P., Poznańska kapituła katedralna schyłku wieków średnich. Studium prozopograficzne 1428-1500, Poznan 2012.

Denifle H, Die älteste Taxrolle der apostolischen Pönitentiarie, Archiv für Literatur- und Kirchengeschichte des Mittelalters 4, 1888.

Dokumenty soborów powszechnych, t. II, opr. A. Baron, H. Pietras, Kraków 2002

Encyklopedia kościelna, wyd. M. Nowodworski, t. I-XXXII, Warszawa-Płock 1873-1913.

Esch A., Wahre Geschichten aus dem Mittelalter. Kleine Schicksale selbst erzählt in Schreiben an den Papst, München 2010.

Fijałek J., Życie i obyczaje kleru w Polsce średniowiecznej, wyd. 2, Kraków 1997.

Göller E., Die päpstliche Poenitentiarie von ihrem Ursprung bis zu ihrer Umgestaltung unter Pius V., t. I-II, Rom 1907-1911.

Helmholz R.H., „Si quis suadente” (C. 17 q. 4 c. 29). Theory and practice, w: Proceedings of the Seventh International Congress of Medieval Canon Law, Cambridge, 23-27 July 1984, Città del Vaticano 1988.

Helmholz R.H., The Oxford History of the Laws of England, t. I: The Canon Law and Ecclesiastical Jurisdiction from 597 to the 1640, Oxford 2004.

Hinschius P., Das Kirchenrecht der Katholiken und Protestanten in Deutschland, t. I-VI, Berlin 1869-1897.

Jóźwiak S., Kwiatkowski K., Szweda A., Szybkowski S., Wojna Polski i Litwy z Zakonem Krzyżackim w latach 1409-1411, Malbork 2010.

Kowalska-Pietrzak A., W kręgu średniowiecznego duchowieństwa łęczyckiego, Łódź-Łęczyca 2012.

Kowalski M.D., Krytyczne uwagi o najnowszym, siódmym tomie „Bullarium Poloniae”, Roczniki Historyczne 73, 2007.

Krupska A., Moniwid Wojciech, w: Polski słownik biograficzny, t. XXI (1976).

Müller W. P., The price of papal pardon - new fifteenth-century evidence, w: Päpste, Pilger, Pönitentiarie. Festschrift für Ludwig Schmugge zum 65. Geburtstag, Tübingen 2004. 
Obyczaje w Polsce. Od średniowiecza do czasów współczesnych, red. A. Chwalba, Warszawa 2004.

Radzimiński A., „,...super irregularitate, si quam propterea incurrit”. Dyspensy ex defectu lenitatis duchowieństwa w okresie pontyfikatu Marcina V, w: Venerabiles, nobiles et honesti. Studia z dziejów społeczeństwa Polski średniowiecznej. Prace poświęcone Profesorowi Januszowi Bieniakowi w siedemdziesiątą rocznicę urodzin i czterdziestopięciolecie pracy naukowej, Toruń 1997.

Radzimiński A., Kobieta w dokumentach papieskich z okresu pontyfikatu Marcina V (14171431), w: Kobieta i rodzina w średniowieczu i na progu czasów nowożytnych, Toruń 1998.

Radzimiński A., Piętnastowieczny formularz z Uppsali jako źródło do badania Kościoła w państwie zakonu krzyżackiego w Prusach, w: Aetas media, aetas moderna. Księga pamiątkowa Henryka Samsonowicza, Warszawa 2000.

Radzimiński A., Życie i obyczajowość średniowiecznego duchowieństwa, Warszawa 2002.

Radzimiński A., Dispensen super defectu perfectae lenitatis. Die Konflikte des spätmittelalerlichen Klerus und die Methoden ihrer Bewältigung, w: Konfliktbewältigung und Friedensstiftung im Mittelalter, Toruń 2012.

Radzimiński A., The women in papal documents of the Late Middle Ages, Quaestiones Medii Aevi Novae 19, 2014.

Radzimiński A., Z życia codziennego polskiego duchowieństwa średniowiecznego. Pobicia, zranienia i bójki (w druku).

Repertorium Poenitentiariae Germanicum. Verzeichnis der in den Suplikenregistern der Pönitentiariae vorkommenden Personen, Kirchen und Orte des Deutschen Reiches, wyd. L. Schmugge i inni, t. I-IX, Tübingen-Berlin-Boston 1998-2014.

Rittner E., Prawo kościelne katolickie, t. I-II, Lwów 1907.

Rybczyk J., Beneficjum, w: Encyklopedia katolicka, t. II, Lublin 1989.

Saczyńska M., Supliki polskich duchownych w archiwum Penitencjarii Apostolskiej (14711492), w: Fundamenty średniowiecznej Europy, Pelplin 2013.

Saczyńska M., Supliki polskie w najstarszej księdze Penitencjarii Apostolskiej (Registra matrimonialium et diversorum, t. 1), w: Ecclesia, regnum, fontes. Studia z dziejów średniowiecza ofiarowane Profesor Marii Koczerskiej, Warszawa 2014.

Salonen K., Schmugge L., A Sip from the „Well of Grace”. Medieval texts from the Apostolic Penitentiary, Washington 2010.

Salonen K., The Penitentiary as a Well of Grace in the Late Middle Ages. The Example of the Province of Uppsala 1148-1527, Annales Academiae Scientiarum Fennicae 313, Saarijärvi 2001.

Salonen K., Kommunikation zwischen der Pönitentiarie und der partes im Spätmittelalter. Die Provinz von Uppsala als Beispiel, w: The Roman Curia, the Apostolic Penitenciary and the Partes in the Later Middle Ages, Acta Instituti Romani Finlandiae 28, 2003.

Schmugge L., Kirche, Kinder, Karrieren. Päpstliche Dispense von der unehelichen Geburt im Spätmittelalter, Zürich 1995.

Schmugge L., Hersperger P., Wiggenhauser B., Suplikenregister der päpstlichen Pönitentiarie aus der Zeit Pius II. (1458-1464), Tübingen 1996.

Steczkowski P., Penitencjaria Apostolska (XIII-XVI w.). Powstanie, ewolucja, odnowienie, Rzeszów 2013.

Tamburini F., Santi e peccatori. Confessioni e suppliche dai Registri della Penitenzieria dell'Archivio Segreto Vaticano (1451-1586), Milano 1995.

Thielen P., Die Verwaltung des Ordensstaates Preussen, Köln-Graz 1965.

Ülhof W., Irregularität, w: Lexicon für Theologie und Kirche, t. V, Freiburg im Breisgau 1960. Urkunden der Komturei Tuchel, wyd. P. Panske, Danzig 1911.

Wojciechowska B., Ekskomunika w Polsce średniowiecznej. Normy i funkcjonowanie, Kielce 2010. 


\section{Dispense De diversis formis für den polnischen Klerus Zur Geschichte des kanonischen Rechts und der Sitten im Spätmittelalter}

\section{Zusammenfassung}

Der Beitrag ist der Analyse der päpstlichen Dispense De diversis formis gewidmet, die an polnische Geistliche adressiert waren und vor allem aus den Registern der Apostolischen Pönitentiarie stammen. Die Dispense wurden vor dem Hintergrund der Tätigkeit dieser wichtigen kirchlichen Einrichtung, ihrer Kompetenzen und der aus dem kanonischen Recht resultierenden Vorschriften besprochen. Denn die Apostolische Pönitentiarie erhielt von den Päpsten das Recht, vier verschiedene Gnadentypen zu gewähren: die Lossprechung von Sünden, die man aufgrund von Verletzungen der Normen des göttliches und des kanonischen Rechts begangen hatte, die Dispensierung von Rechtsbrüchen innerhalb des kanonischen Rechts, die Erteilung von Lizenzen verschiedener Art für Aktivitäten, die nicht mit der herrschenden Praxis vereinbar waren, sowie die Abgabe von Erklärungen in verschiedenen Angelegenheiten. Die von polnischen Geistlichen in ihren an die Pönitentiarie adressierten Suppliken berührten Fragen gehörten zu sieben Kanzleikategorien. Es handelte sich dabei um Bitten im Umkreis des Ehesakraments und der illegitimen Geburt, um den Erlaß entsprechender Erklärungen, um Pfründenfragen, um Fragen zum Eintritt in den geistlichen Stand und zur Erlangung von Weihen sowie um Fragen zum Bußsakrament. Unter den sieben Dispenskategorien war auch eine Kategorie vertreten, die mit der Bezeichnung De diversis formis umschrieben wurde. Der in dieser Form an die Apostolische Pönitentiarie vorgebrachten Bitte um Dispensierung ging vornehmlich Gewaltanwendung und Waffenbenutzung durch Geistliche, deren Teilnahme am Krieg oder eine vorsätzlich oder fahrlässig herbeigeführte Tötung voraus. Ihre rechtliche Analyse erlaubte die Beantwortung zahlreicher Fragen im Zusammenhang mit den Kenntnissen, dem Verständnis und der Anwendung des kanonischen Rechts innerhalb des polnischen Klerus während des Spätmittelalters. Breiten Raum nimmt auch die Darstellung der sehr interessanten und mit dem Alltagsleben verbundenen sittlichen Ebene ein, mit der ein vertiefter Einblick in die Funktionsweise dieser gesellschaftlich-berufsmäßigen Gruppe möglich ist.

Übersetzt von Waldemar Könighaus

\section{Dispensations de diversis formis for Polish clergy From the history of applying canon law and customs in Late Middle Ages}

Abstract

The article discusses dispensations de diversis formis received by Polish clergymen at the Apostolic Penitentiary. The topic is presented with reference to the activities of that Papal institution, its area of competence and the rules of Canon Law relevant to it. The main thesis which is put forward in this context, concerns the knowledge, understanding and observance of the rules of Canon Law that were in force. The paper also presents very interesting references to customs connected with everyday life of the clergy.

Translated by Rafat T. Prinke 